布の水分伝達特性の評価に関する 2,3 測定

\title{
A FEW MEASUREMENTS ON THE EVALUATION OF THE PROPERTIES OF TRANSMISSION OF WATER IN FABRICS
}

\section{By Atsushi Suzuki}

(Department of Home Economics, Faculty of Education, Nagasaki University, Nagasaki)

Lately developments of water absorbent synthetic fibers have become of general interest and the related reports are increasing. In this paper the properties of transmission of water in the related fabrics were estimated from the sliding resistance and the heat flow, the methods of which were derived in the past. It was suggested that water absorption of porous synthetic fiber, the blended of porous synthetic fiber and cotton fiber or the double layer of cotton and polyester contributed to the physical factors of comfort.

(Received June 22, 1982)

\section{1.はじめに}

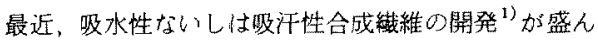
で，その「著心地」《関する機能性要团の評価の研究 ${ }^{2)}$ 李行われてきている。

そこで本報告ですこれら新しい素材を含めたいくつか の布試料について，その对水尔機能在従来筆者らが取り

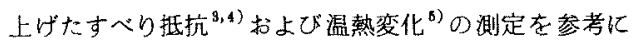
検討したのでその結果について報告する。

\section{2. 測定内容およひ測定法}

\section{1 試 料}

用いた試料は親・踈水性䋞維別の吸湿性之ぬれ易さに 特徏をむつ表 1 亿示す各試料を選択した。試料の諸元は

Table 1 Details of samples.

\begin{tabular}{|c|c|c|c|c|c|c|c|c|c|c|c|}
\hline \multirow[b]{2}{*}{ No. } & \multirow[b]{2}{*}{ Sample } & \multirow[b]{2}{*}{$\begin{array}{l}\text { Texture } \\
\text { (Knit) }\end{array}$} & \multirow[b]{2}{*}{$\begin{array}{c}\text { Count } \\
(s)\end{array}$} & \multicolumn{2}{|c|}{ Density } & \multirow[b]{2}{*}{$\begin{array}{c}\text { Thickness } \\
\left(\times 10^{-2} \mathrm{~cm}\right)\end{array}$} & \multirow{2}{*}{$\begin{array}{l}\text { Weight } \\
\left(\times 10^{-3}\right. \\
\left.\mathrm{g} / \mathrm{cm}^{2}\right)\end{array}$} & \multirow{2}{*}{$\begin{array}{l}\text { Air } \\
\text { permeability } \\
\left(\mathrm{cc} / \mathrm{cm}^{2} \mathrm{sec}\right)\end{array}$} & \multirow{2}{*}{$\begin{array}{c}\text { Moisture } \\
\text { regain } \\
(\phi)\end{array}$} & \multirow{2}{*}{$\begin{array}{l}\begin{array}{c}\text { Contact } \\
\text { angle } \\
\left({ }^{\circ}\right)\end{array} \\
\end{array}$} & \multirow{2}{*}{$\begin{array}{l}\text { Rate of water } \\
\text { absorption } \\
(\mathrm{mm} / 10 \mathrm{~min})\end{array}$} \\
\hline & & & & \begin{tabular}{|l|} 
Coause \\
$(\mathrm{c} / \mathrm{cm})$
\end{tabular} & $\begin{array}{l}\text { Wale } \\
(\mathrm{w} / \mathrm{cm})\end{array}$ & & & & & & \\
\hline 1 & Cotton & $\begin{array}{l}\text { Rib } \\
\text { stich }\end{array}$ & $42.5 / 1$ & 13 & 19 & 7 & 5.2 & 181 & 7.9 & 55 & 110 \\
\hline 2 & Acrylics & $"$ & $150 \mathrm{~d}$ & 13 & 18 & 4.1 & 11 & 221 & 1.5 & 53 & 80 \\
\hline 3 & *1 & " & $1 / 49.3$ & 15.4 & $"$ & 6 & 17 & 158 & - & - & 60 \\
\hline 4 & $* 2$ & " & $1 / 60$ & $"$ & 9.5 & 12 & 22 & 103 & - & - & 131 \\
\hline 5 & $\begin{array}{l}\text { Cotton } 65 \% \\
\text { /Acrylics } 35 \% \\
\end{array}$ & " & $1 / 33.2$ & 11.5 & 16 & 7 & 17 & 140 & - & - & 96 \\
\hline 6 & \begin{tabular}{|l|} 
Cotton \\
Polyester
\end{tabular} & $\begin{array}{l}\text { Plain } \\
\text { knitting }\end{array}$ & $1 / 73.0$ & 17 & 15 & 5 & 9.5 & - & - & - & 93 \\
\hline 7 & Wool & $"$ & $1 / 37.3$ & 13 & 15 & 7 & 16 & 183 & 14.1 & 81 & 0 \\
\hline 8 & Polyester & $\begin{array}{l}\text { Rib } \\
\text { stich }\end{array}$ & $82.5 \mathrm{~d}$ & 15 & 13 & 8.6 & 13 & 177 & 0.4 & 69 & 38 \\
\hline 9 & Acrylics & 11 & $144 d$ & 13 & 18 & 4.4 & 10 & 221 & - & 66 & 0 \\
\hline
\end{tabular}

*1 Surface absorbent

*2 Porous

*3 Face : Polyester, Back : Cotton 
次のような測定法に準挟し，測定は標準状態 $\left(20^{\circ} \mathrm{C}, 65\right.$ \% RH)で行った。厚さ，通気度，棡軟度等の測定につ いては，それぞれ織物厚さ計，フラジール型通気度試験 譏找よびハートループ法による用軟度試験器等を用いて 測定した。吸水速度はバイレック法による測定值を示し， 吸湿率は標準状態の吸湿率で示した。接触角については 緎維に水滴を噴婑し，その顕微鏡写真から計測した。

\section{2 力学的測定}

\subsection{1 湿潤布のすべり抵抗の测定}

既報 ${ }^{3 》}$ の方法に隼拋した図 1 亿示す測定装置により水 分率一すべり抵抗曲線を求めた。すなわち最初に重さの 分っている標準状態にある試料老接続子に固定し，その 裹面をポリプロピレンフィルム上に接触させる。ついで

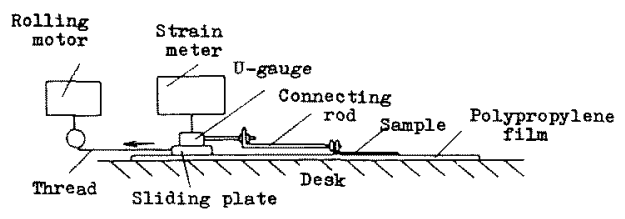

Fig. 1 Schematic diagram for measuring the sliding resistance of the wet fabric.
布が過飽和に湿堆するまでピベットまたはマイクロシリ ンジで一定嘼の蒸留水を試料に含浸させる。そしてての 上きの乾燥重量に対方布の水分率 $W_{\mathrm{s}}(\%)$ 老読み取。 ておく。その後は自然乾燥の状態に保ち，任意心経過 時間 $t_{\mathrm{t}}(\mathrm{min})$ 飞拈り万水分率 $W_{\mathrm{t}}(\%)$ でのすべり抵抗 $R_{\mathrm{t}}$

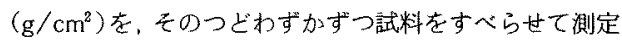
する。をして一連の水分率における湘定を終った後の経

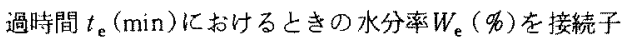
加ら試料を取りはずして自動天秤にて秤量する。この上 き実測時と同じ状態での布の乾燥速度がすべり抵抗の実 測籍同内で一定であるととから $\mathrm{t}$ 時間に扔ける水分率 $W_{\mathrm{t}}$ は次式に上って決定される。

$$
W_{\mathrm{t}}=W_{\mathrm{s}}-\left(W_{\mathrm{s}}-W_{\mathrm{e}}\right) \cdot\left(t_{\mathrm{t}} / t_{\mathrm{e}}\right)
$$

すなっち以上の結果から $W_{\mathrm{t}}$ 上 $R_{\mathrm{t}}$ 上の関係が求められ る。実験は温度 $20^{\circ} \mathrm{C}$, 湿度 $65 \% \mathrm{RH}$, 風速 $30 \mathrm{~cm} / \mathrm{sec}$ の恒温恒湿奏数室で行った。

\section{2 .2 液滴吸收時におけるすべり抵抗の䁚定}

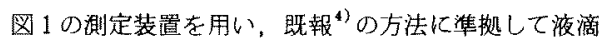
吸収時の経過時間一すべり抵抗曲線を求めた。すなわち すべり抵抗の測定をあらかじめ開始させておき，その状 態のままで試料の後端を持ち上げポリプロピレンフィル
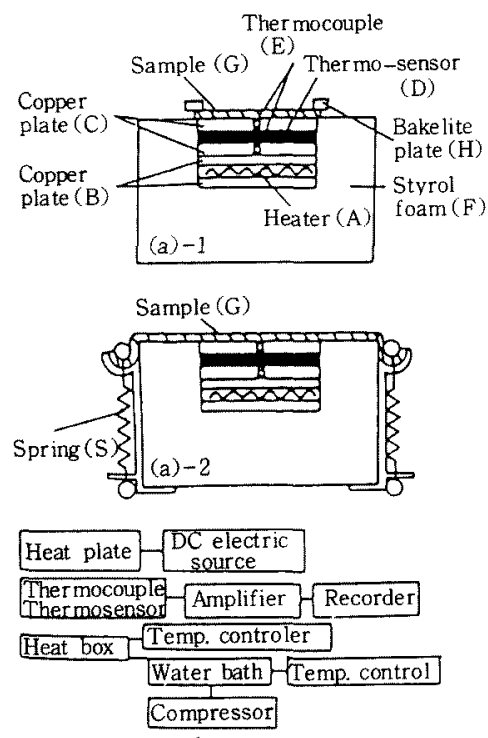

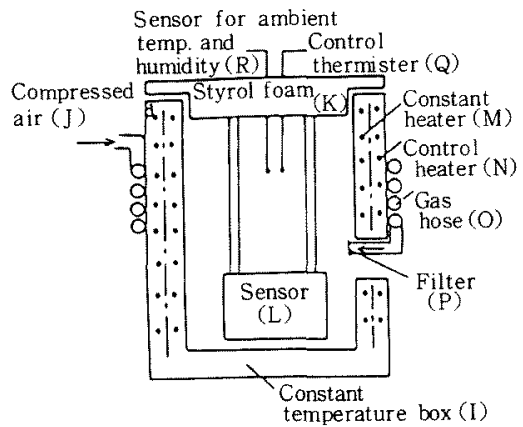

(b) -1

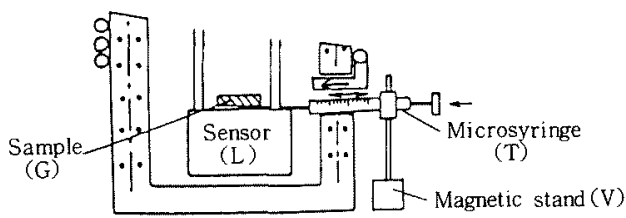

(b) -2

(c)

Fig. 2 Schematic diagram for measuring the changes of temperature and heat flow. (a)-1 and (b)-1 Schematic diagram of main parts of the apparatus for measuring the changes of temperature and heat flow in the period of drying of wet fabric. (a) -2 and (b) -2 Schematic diagram of main parts of the apparatus for measuring the change of heat flow in the period of absorption of water-drop of fabric.

(c) System for recording the changes of temperature and heat flow. 
ム上に液滴を滴下する。そして試料 をポリプロピレンフィルム上接触 させ，液滴吸収に伴う布のふさとり 能力とすへり抵抗とり関係を求奴。 液滴量は $1 / 50 \mathrm{cc} と し$, 测定は前項 の実験同様恒温恒湿実験室で行った。

\section{3 熱的測定}

2.3.1 湿潤布の温熱变化の測定 既報ら)の方法に準揵した(風量が 異子马)图 20 (a) - 1, (b) - 1, (c) の測定方法に上り水分率一温度変化 曲線ならびに水分率一熱流量変化曲 線を求めた。すなおち測定は熱板に 接触させた試料を過飽和に湿潤させ て，その乾燥過程に扔ける試料下の 温度ならびに熱流覧の変化特性を測

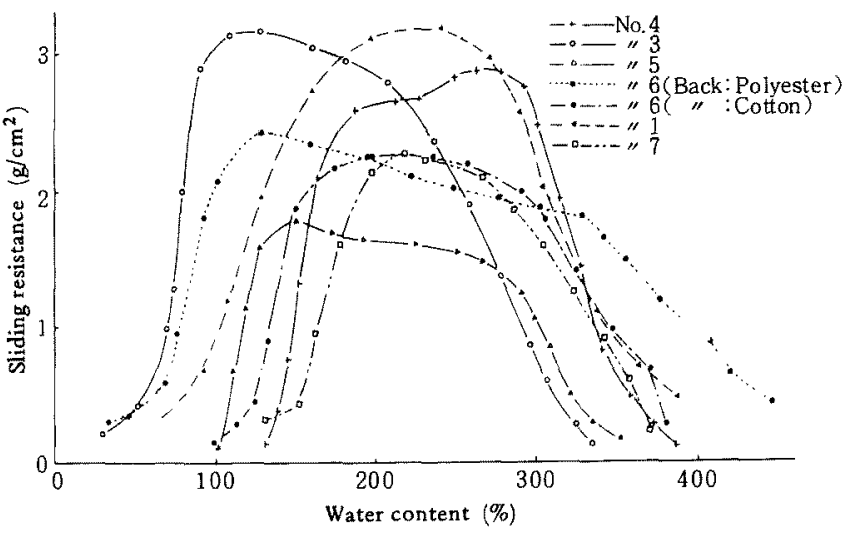

Fig. 3 Relation of the sliding resistance of knit fabrics and water content.

定した。このとき，実呀は最初乾燥過程の全体について 测定し，以後，乾燥過程の中途段階で測定を中断し，そ の時点での布の水争率を自動天秤にて実測し，各测定点 での温度ならびに熱流量の対水尔率曲線を求めたもので ある。

2.3.2 液滴吸収上熱変化の測定

2.2.2 項に対応する新しい熱的訐価法として図 2 の (a) $-2 ，(b)-2$ ，(c) の测定方法に上り，液滴吸収時に おりる熱流変化を测定した。まず図の(a)-2のセンサー に試料幅 $3 \mathrm{~cm}$ の試料を装着する。このとさ試料は垂下 $5 \mathrm{~g}$ 下においてスプリングSにて固定する。そしてセン サー部分を図の(b)-2に設置し，試料下の中心部分に マイクロシリンジの先端が位置するようにマグネット スタンドVにセットする。その後前項の測定之同じ環境 下で定常状態になった段階で液滴を滴下し素早くマイク ロシリンジを抜き出し㳸滴吸取に伴う熱流変化を測定し た。液滴量は $4.8 \mu$ とした。

\section{1 実験結果および考察}

\section{1 力学的測定結果}

3.1 .1 水分率よすべり抵抗之の関係

园3にすへり抵抗一水分率曲楾の測定結果を示した。 それによるとつぎのようなととがいえる。No.3のアク リル試料は他の試料に比較して水分率の低いととろです ベり抵抗が急增しており，その最大值も大きく，曲線全 体加低水分側に位䈯している。それは比较的密度が大き く薄地で布を構成している維維が吸湿性が少なくかつ表 面変性型の吸水瀻維であるととから抱水能力に限界があ るためである。No.4のアクリル試料では㵶維自身の昅 湿性は少ないが紻維が微紐空孔を有しており，加つ布地
も厚地であるととから抱水能力にすぐれ，No.3の試料 に比べてすへり抵抗の急増がかなり高水分側にずれた結 果を与えている。No. 5 の試料は多孔質の吸水性アクリ ル繶維と綿との混紡品で、前 2 者に比較してかなりすへ り抵抗が小さい特徵を示している。つまり布構成条件の 違い住ともか人吸湿性をむつ綿之多孔質の吸水性瀻維之 に上る相乗效果が密着性の緩和作用上してかなり效果的 に㗢いているもの之推察される。No.6の綿よポリエステ ルの 2 層構造からなる試料では，すべり面が綿の場合の 方が ポリエステルの場合よりる水分による抵抗を受り にくく，高い水分率の上ころですべり抵抗が急増してい る。No.7の羊毛ではすべり抵抗一水弥摔曲線があっと 皇高水分率側に位置し，No.1の綿では中間的な存在に あり，すべり抵抗の大きさがぬれ易い綿では大きく，ぬ れにくい羊毛では小さい特㗂 ${ }^{2,8)}$ を示している。

3.1 .2 液滴吸取上すべり抵抗との関係

図4は液滴吸収時におけるすべり抵抗の測定結果であ る。その結果は図 3 の結果を更侍特づけるもので，

No. 5 の多孔質吸水性アクリ儿織維亡綿との混紡品がす ベり抵抗の作用が小さく，密着性が小さい点で優机てい る。そして多孔質緎維のみからなる No. 5 の試料では混 紡品ほどの効果が期待できないようである。No.6の椾 リエステルと綿よの 2 層構造のうち，接触面が綿の場合 の結果むかなり小さい特徵を与えている。勿論，布の構 成条件が必ずしも同一ではないので，定量的な比較はで きないが吸湿性がある䋐維とない絨維(ぬれ易い場合と ぬれにくい場合がある)之をうまく取り合わせるととに 上り何らかの相乗効果が期待されるようである。No. 3 の表面加工型の吸水性アクリル緎維や, No. 2 のレギュ ラーアクリルの場合には抱水能力の点で少っており，密 


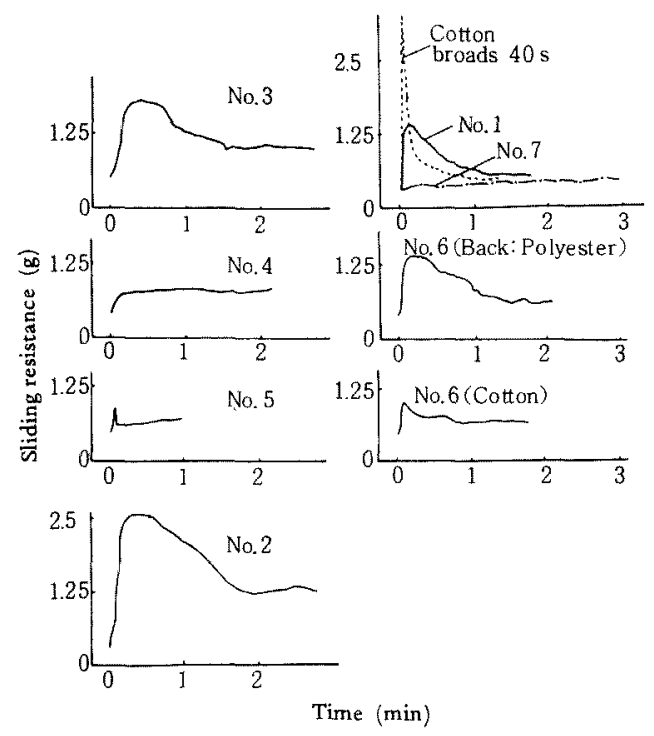

Fig. 4 Relation between the sliding resistance of knit fabrics and the liquid absorption.

着性を減少させる上で余り大きな期待はできないようて ある。な相には綿ブロード40sの結果す付記したが メリヤス地に比へてすべり抵抗がかなりシャープで最大 值あ大きいとと加仯る。つまりこれは肌着がメリヤス地 であるととの根挻の一つともいえる。No.7の羊毛では ぬれにくく特に毛管作用が㗢かず特殊である。

\section{2 熱的測定結果}

\subsection{1 水分率之温熱変化との関係}

吸水布の乾燥過程におりる温度 $T\left({ }^{\circ} \mathrm{C}\right)$ 括よひ熱流量 $H$ $\left(\mathrm{kcal} / \mathrm{m}^{2} \mathrm{hr}\right.$ )の変化結果を対水分率曲線として図 5 仁示 した。その結果は既報り之同様いわ加典型的な乾燥機 構を示すむので，水分率がある大きさ以上のとこるでは 温度书よび熱流量が水分率の大きさにかか力らずほぼ一 定で，いわゆる恒率乾燥期間にすり，之れ以下では减率 乾燥期間にあることが分る。

まずての恒辩乾燥期間の限界水分率 ${ }^{5,7)}$ を推定してみ ると大略表 2 に示す通りである。すなわち多孔質の吸水 性アクリル瀻維と綿との混紡品 (No. 5)や接螌面が綿の 場合の2 層構造(No.6)加らなる試料ては限界水分率が 綿試料(No.1)に近くはほ30\%程度之高く, 多孔質の吸 水性アクリル䋞維のみからなる試料(No.4)や接触面か ポリエステルの場合の2 層構造からなる試料(No.6)で はほぼ20\%程度とやや低い值を示している。そしてNo. 3の表面吸水型のアクリル䧕料(色香の)でははぼ $10 \%$ 程度と更に低い值を示している。このととは表面改質型

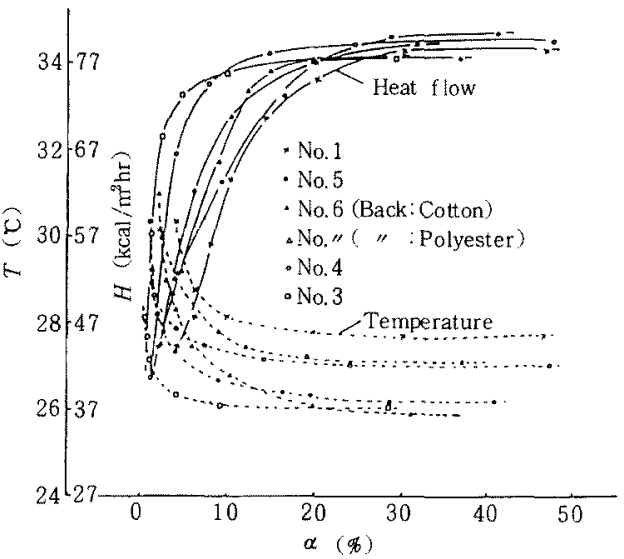

Fig. 5 Changes of temperature $T$ and heat flow $H$ versus water content in drying of wet fabric.

Table 2 Observed values of the critical water content.

\begin{tabular}{|c|c|c|c|c|}
\hline No. & Sample & Texture & $\begin{array}{l}\text { Critic } \\
\text { water }\end{array}$ & content \\
\hline 1 & Cotton & $\begin{array}{l}\text { Rib } \\
\text { stich }\end{array}$ & About & $30 \%$ \\
\hline 4 & Acrylics & $" 1$ & 11 & $20 " 1$ \\
\hline 3 & " & "I & "I & $10 "$ \\
\hline 5 & $\begin{array}{l}\text { Acrylics } 65 \% \\
\text { /Cotton } 35 \%\end{array}$ & $" \prime$ & $"$ & $30 "$ \\
\hline 6 & $\begin{array}{l}\text { Polyester (face) } \\
\text { Cotton (back) }\end{array}$ & $\begin{array}{l}\text { Plain } \\
\text { knitting }\end{array}$ & $"$ & $30 "$ \\
\hline " & $\begin{array}{l}\text { Cotton (face) } \\
\text { Polyester (back) }\end{array}$ & " & $"$ & $20 "$ \\
\hline
\end{tabular}

(実際注バイレック法化よる吸水速度がNo.20レギ ュラーアクリルより No.3の方が小さい)が多孔質型に比 へて抱水量に限界があるてとを意味している。また多孔 質の吸水性試料の場合バイレック法による吸水速度は綿 以上であるが，熱的に求めた限帮水分率は䄸より小さく 抱水能力つまりは物理的な吸水性(多孔質)といわゆる吸 湿性との間でその動きに違いのあるととが示唆される。

つぎに図 5 の結果を図 6 の指数関数で表わし $\left(H_{0}, T_{0}\right.$ は恒率乾燥期間の温度 ( $\mathrm{C})$ 扰よび熱流量 $\left(\mathrm{kcal} / \mathrm{m}^{2} \mathrm{hr}\right)$ の值である)，減率乾燥期間に括りる第 2 限界水分率を 求的てみるとほぼ表 3 のうとなる。すなわちその結果

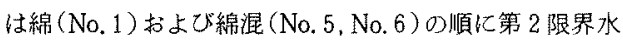
分率が高く，多孔質型の吸水化のみでは第 2 限界水分率 を高める上で限界のあるととが示唆さ机る。

3.2 .2 液滴吸収上熱変化特性

图 ๆは液滴吸収時における熱流量の変化特性を示した 


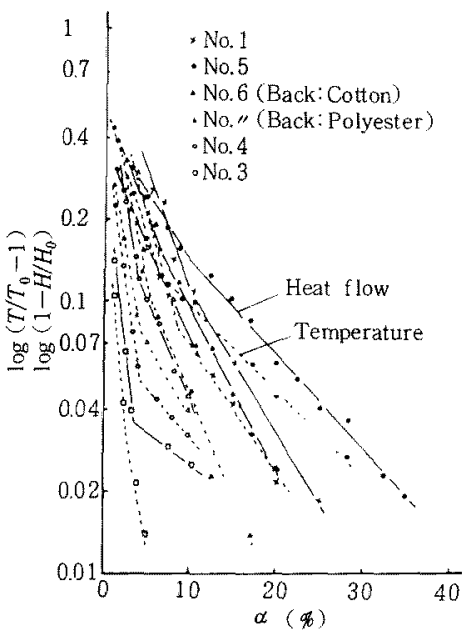

Fig. 6 Relation between $\log \left(T / T_{0}^{*}-1\right)$ and $\log \left(1-H / H_{0}\right)$ and $\alpha$.

Table 3 Observed values of the second critical water content.

\begin{tabular}{|c|c|c|c|c|}
\hline No. & Sample & Texture & \begin{tabular}{|l|}
$\begin{array}{l}\text { Second } \\
\text { water }\end{array}$ \\
$\mathrm{H}_{2}(\%)$ \\
\end{tabular} & $\begin{array}{l}\text { critical } \\
\text { content } \\
T_{2}(\%)\end{array}$ \\
\hline 1 & Cotton & $\begin{array}{l}\text { Rib } \\
\text { stich }\end{array}$ & 13 & 9.5 \\
\hline 4 & Acrylics & $" \prime$ & 4 & 4 \\
\hline 3 & " & $"$ & 3.5 & 25 \\
\hline 5 & $\begin{array}{l}\text { Acrylics } 65 \% \\
\text { Cotton } 35 \%\end{array}$ & $"$ & 10.5 & 6.5 \\
\hline 6 & $\begin{array}{l}\text { Polyester (face) } \\
\text { Cotton (back) }\end{array}$ & $\begin{array}{l}\text { Plain } \\
\text { knitting }\end{array}$ & 6.5 & 5.5 \\
\hline " & $\begin{array}{l}\text { Cotton (face) } \\
\text { Polyester (back) }\end{array}$ & $"$ & 5 & 4.5 \\
\hline
\end{tabular}

あのである。そのパターンは両極に吸湿性が小さくぬれ 舅い試料と吸湿性が大きくぬ好にくい試料とが存在し， 前者では短い経過時間に対して熱流量加急增し，加つ急 堿するシャープな形状を示し，その熱流速度の最大值も 大きい。後者で法経過時間に対して，熱流量の上昇が緩 慢で放熱時間が長く，形状はフラットで，熱流速度の最 大值汃小さいそしてぬれ之吸湿性が共に大きいか共に 小さい場合に両者の中間的特徵を示し，前者ではぬれが 大きく吸湿性が小さい場合の結果に類似し，後者ではぬ れが小さく吸湿性が大きい場合の結果に類似したパター ンを示す。たとえば吸湿性が少なく織維表面のみが女れ 易いアクリル試料（No.2，No.3)では抱水能力が小さく， 毛管漫透に上る浸透速度屯浸透面積む大きく，その結果 蒸発面皘が大きくなり，加つ被接触面の好度も大きく， 彾却されやすい性質化あるといえる。圾お，No. 602 層構造り場合に舟じような効果が認められる。一方吸 湿性が大さく，㞦にい羊毛試料ではをの逆の性質を 示し, 四5の䊅果加あ分るように羊毛の保温效果の一 端它説明しているといえる。

\section{4. 結}

眀湿性とぬれ易さに特徽をむつ布の水分伝達特性につ いて検討するため2，3の力学的扔よび熱的测定を試み た。その結果加ら多孔質の吸水性アクリ儿緎維，その綿 との湿綡，あるいは親・䠅水緒維による 2 層構造などの 水分伝達特性に関するパターンの特徽を知り，それらの 性質が着用時の機能性要因の改善に春与することの示唚 を得た。特に綿と多孔質の吸水性アクリル瀻維との混紡 に拉いて有效であるととの知兒を得た。反面多孔質性が

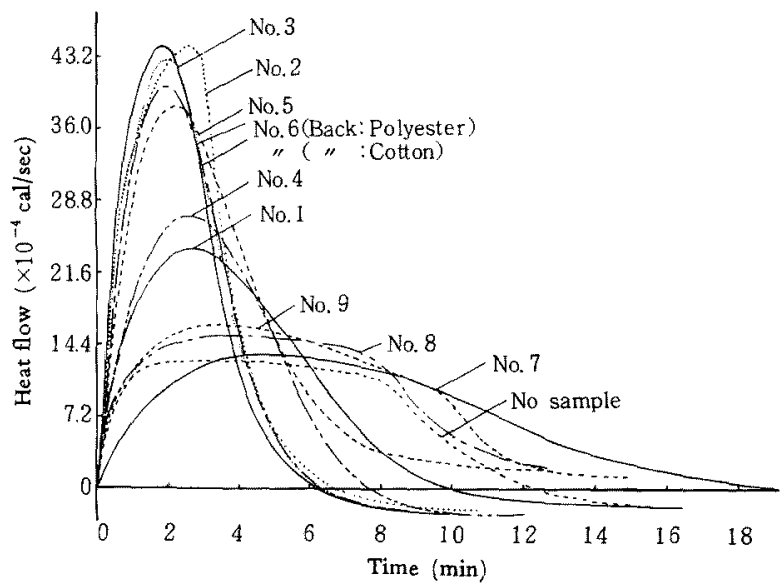

Fig. 7 Relation between heat flow and elapsed time in the period of absorption of water-drop by fabric. 
示す吸水性といわれる吸湿性との間にはをの性質にかな りの差のあるととも示㛺された。なお，今後更に測定例 をふやして検叶するてとが必要である。

ここで試料の恵与を頂きましたととを厚く感謝致しま す。

\section{文献}

1) 大口; 綪学誌, 37, P-252(1981)

2）たとえば福井，関口；䄉学誌，36，P-313 (1980):

松井，近藤，荒井，山本；䋐学誌，37，P-101
(1981): 蕏岡，丹羽; 家政学誌, 30, 320(1979)： 营井，中皂：織消䚉科学会昭和 57 年年次大会研究 発表要旨p. 114

3）鈴木，新海，大平；䋐学范，29，T-51 (1973)

4) 鈴木，大平；緎維学論文集，26，T-217（1973）

5) 鈴木; 瀻学誌, 38, T-163(1982)

6) 鈴木; 緎学誌, 39, T-233 (1983)

7) 中島, 進藤；瀻学誌，37，T-347(1981)；菅井。 中島；日本繊消費科学会昭和 57 年年次大会研究発 表要旨 p. 114 